\title{
Family Farming, Land Use and Sustainability in the Amazon: Focusing on the Educational Dimension
}

\author{
Raimundo Cláudio Gomes Maciel ${ }^{1}$, Francisco Diétima da Silva Bezerra², \\ Francisco Carlos da Silveira Cavalcanti ${ }^{1}$, Oleides Francisca de Oliveira ${ }^{1}$, \\ Pedro Gilberto Cavalcante Filho ${ }^{1}$
}

${ }^{1}$ Centre for Applied Social and Legal Sciences (CCJSA), Federal University of Acre (UFAC), Rio Branco, Brazil

${ }^{2}$ Acre's Federal Institute of Education, Science and Technology (IFAC), Rio Branco, Brazil

Email:rcgmaciel@ufac.br, francisco.bezerra@ifac.edu.br, fcscarlito@uol.com.br, pedro.gilberto@hotmail.com

How to cite this paper: Maciel, R. C. G., da Silva Bezerra, F. D., da Silveira Cavalcanti, F. C., de Oliveira, O. F., \& Filho, P. G. C. (2018). Family Farming, Land Use and Sustainability in the Amazon: Focusing on the Educational Dimension. Creative Education, 9, 99-114.

https://doi.org/10.4236/ce.2018.91009

Received: December 25, 2017

Accepted: January 28, 2018

Published: January 31, 2018

Copyright $\odot 2018$ by authors and Scientific Research Publishing Inc. This work is licensed under the Creative Commons Attribution International License (CC BY 4.0). http://creativecommons.org/licenses/by/4.0/

\begin{abstract}
The struggles for land possession and deforestation were some results of the recent occupation process in the Amazon. Family farming was the target of land policies in the region, with recurring failures. Issues related to land governance and pro-poor policies have returned to the discussions, especially by the food production. This study aims to evaluate the relationship between the educational level, land access and sustainable land use among farmers in Acre State, Brazil, in the periods 1996/1997 and 2006/2007. Based on a sample, the methodology worked with variables related to the educational level, the access and the use of land, economic results and solid garbage. The results show that the higher educational level is directly related to the land access security and inversely proportional to sustainability in the land use type. Furthermore, production difficulties are leading to greater market dependence and, consequently, to increased generation of solid garbage, whose disposal may be better directed by improving the farmers' education.
\end{abstract}

\section{Keywords}

Family Farming, Education, Land Governance, Sustainability, Amazon

\section{Introduction}

The Amazon occupation process, after 1970, led to dismantling of traditional extractivism in the region, and encouraged the implementation of "modern" activities such as agriculture. Some results of this process were the immense deforestation, the fight for land, the urban suburbs formation and their social problems (Maciel, 2007). 
Therefore, the land that was important to the traditional population livelihood turned into property speculation objected by the land grabbers, big businessmen, among other agents, leading to land conflicts in the region, and with the important resistance of the rubber tapper social movement.

In the content of land struggle in the Amazon, the Federal Government encouraged the colonization of this region from several projects in the 1970s, led by the newly created National Institute of Colonization and Agrarian Reform (INCRA), with migrant family farmers from different Brazilian regions, but with no success.

In the following decades, because of the difficulties of social reproduction of families in the countryside, it was performed some adjustments in Brazilian land policy through many forms of rural settlements, including in forest areas, such as the Extractive Reserves and Sustainable Development Projects.

Thereby, environmental issues have become important to define the type of settlement to be developed, in view of the discussions on land use, particularly about the deforestation levels in forest areas and the projects' environmental sustainability.

However, the results also proved unsatisfactory considering the difficulties to access to land, markets, appropriate technologies, leading to several questions, especially on rural poverty.

Nonetheless, some variables aren't focused enough about the adopted land policies, even when they are worked from the modern concept of land governance, especially in the discussion on sustainable development, once the economic view is still prevalent in many policies to the detriment of social and environmental dimensions. So, it may be asked: Does the land access ensure the security of property and sustainable land use?

Thus, this study aims to evaluate the relationship between the educational level, access to land and sustainable land use among farmers in Acre State, Brazil, in 2006/2007 period.

The hypothesis is that access to land is important to the production of goods and services and income, but it doesn't guarantee the land use sustainability because other factors influence this process, such as the level and type of education received by the population involved.

This work is very important towards the need to subsidize public policies for the Amazon region, particularly in Acre State, focusing on family farming which lacks effective policies for sustainable development.

\section{Family Farming and Land Governance}

Family farming is the broadly dominant form of agricultural production in the world. The FAO (2014) estimates the family farming produces more than $80 \%$ of food in a sample of 30 countries. Furthermore, family farming is considered as multifunctional once it contributes to ensure the ecosystem services, biodiversity, landscape conservation, rural economy, among others (Quan, 2015). 
According to Guanziroli et al. (2001), rural family farmers have advantages in labor management, especially in critical and demanding jobs in careful cultivation. Furthermore, family farming holds the rural exodus, generates local labor and diversified production systems, also seeking more sustainable productive activities.

Recent discussions about the food production and biofuels and their prices, related to large corporations or family farm, has focused on issues of competition for land use, land market, land control, among others. Thus, the concept of land governance has gained acceptance in international development agencies, as well as pro-poor land policies around the world (Borras \& Franco, 2010).

According Reydon (2014: p. 754) the land governance concept of FAO (2009) would be considered the most appropriate:

The Governance is the system of values, of policies and of institutions by which society manages its economic, political and social issues through interactions among the government, the civil society and the private sector. The Land Governance refers to the rules, processes and organizations, and by them make decisions about land access and its use, the way in which they implement these decisions and how they manage land's conflicts of interest.

An initial perception about this concept refers to the discussion regarding the sustainable development concept. As Romeiro's ideas (2012), the proposals to achieve sustainable development are regulations on how it can and should be development. Similarly, maybe it can frame the land governance concept, particularly in underdeveloped regions, since the reality is far from what should and can be land governance. Many challenges are imposed between the regulation and reality, which they haven't adequately addressed yet.

In this process, like Borras \& Franco (2010) stated, the economic bias is raised as preponderant in many discussions, such as the cadaster and land titling in the land market regulation. However, according to Payne, Durand-Lasserve, \& Rakodi (2009), land titling programs often fail in implementing the promised benefits, for example, in fighting poverty, once there are no sufficient evidence in reducing poverty levels, or the security in land access.

So, it is worth emphasizing that land issues have multidimensional character, like the indigenous territories issues, crucial for the socio-cultural reproduction of these people (Borras \& Franco, 2010).

Social relations based on land are fundamental to the routing of discussions on land governance, because land issues are social relationships between people. Governance is about political relations between groups of people and institutions that govern them. Social relations based on land are continuous and they change constantly, even long after the certification process or a finalization of a land reform program. "The bottom-line is about reforming land-based social relations" (Borras \& Franco, 2010). 
However, it is notable that even in areas where security of land tenure has been resolved, for example in official settlements project in the Amazon, several other issues haven't been resolved, such as sustainable land use. Many variables haven't been sufficiently or adequately studied, such as the educational level of these people, especially in rural areas. In this sense, this study aims to contribute in the discussions in the next topics.

\section{Education for Sustainable Development}

Environmental problems present in contemporary society, resulting from uneven and predator development model which was implemented, warn us to the need to motivate and sensitize the population to modify their behavior in order to ensure good quality and preservation of the environment with justice and social equity (Jacobi, 2004; SÁ, 2008). According to Gadotti (2010), to formation a new consciousness toward environmental preservation, it is necessary to associate the sustainability with education, considering that environment preservation depends on the ecological awareness, and it in turn depends on the education. For Gottlieb et al. (2011) the education for sustainability is extremely important to break the unsustainable development models, increasing in the citizen the spirit of responsibility and solidarity among generations.

In this context, Komiyama \& Takeuchi (2006) argue that sustainability emerges as the key issue for the society of the twenty-first century, as in its concept approaches the need for a balanced development with the environment, while ensuring fairness social for future generations. Coupled with sustainability, education plays a key role in controlling and overcoming the various crises present in society-environmental, economic, social and cultural-through the formation of citizens able to intervene consciously and responsible.

Related to this, Barbieri \& Silva (2011) assert it's from that realization that education is being discussed in several international conferences as a key issue and essential to overcoming various environmental problems. But in all these conferences, there was some consensus that the formulation and implementation of an environmental education project (EA) worldwide should be implemented at regional and local level, requiring the environmental heritage preservation.

However, as Henriques et al. (2007), Barbieri \& Silva (2011), the results achieved by EA over the years have been insufficient in the face of various problems present in the global society, being necessary to resort to a new education proposal contemplating a wider range of aspects in its approach. It was in this context of limitations and dissatisfactions on the advances promoted by EA throughout its existence, which gets a new proposal within the framework of the United Nations (UN), called “Education for Sustainable Development” (EDS).

According to UNESCO (2005), EDS has as main feature the transversality, present in all curricular components, as it includes in its conception the many socio-cultural and political issues, as social equity, poverty, democracy and qual- 
ity of life. Furthermore, EDS should promote critical thinking and problem solving; use multiple methods; encourage student participation in the decision-making process; integrate into daily routine the offered learning experiences; handle local and global issues, using the students' common language (UNESCO, 2005).

Thus, EDS is defined as a continuous process for the entire life, in formal and non-formal context of teaching and learning; with a transdisciplinary approach to content and information, given the complexity of problems such as poverty, inequality, democracy, etc., and buoyed for and by solidarity values towards present and future generations; with citizens' critical training to act effectively in promoting social, economic and environmental development; Furthermore, it should be guided by democratic principles and processes ensuring individuals an active, conscious and responsible in dealing/solving the several problems present in society; and finally, the EDS should promote scientific and technological understanding of the issues treated in order to encourage the involvement of citizens in leading a more sustainable planet (UNESCO, 2005; SÁ, 2008; Veiga, 2014).

\section{Field Education: The Pursuit of Institutional Change}

Even with the recognized importance that education has an essential role in the behavioral change process, especially in relation to ethical and sustainable consumption, contributing to environmental improvement, the education in Brazilian rural areas has faced many difficulties through the years. It happens due the agricultural development model implemented in Brazil defended (or defends) an education model facing urban areas, valuing the great capital. That model was taken to the countryside, without regard the reality experienced by the field individual (Caldart, 2004; Prazeres \& Souza Do Carmo, 2012).

In Brazil, there is a diversity of people living in diverse areas, different one of another, which prevents the application of the same policy in various territories. According to Oliveira \& Hage (2011: p. 143), "this diversity of populations, each one with own way of life, contributes to each area of the field, amid the general aspects produced by the totality of capitalist relations, has singularities which differs one from others and from urban areas".

According to Caldart (2004), the struggle for education provision in the field, from the 90s, occurred concomitantly with the fight started by MST seeking to have the rights guaranteed in relation to land tenure. Initially, there was little relationship between these two fights, but gradually the struggle for the right to school became part of the masses' social organization in the struggle for agrarian reform, which became the MST. An important point which favored the struggle for the field's school quality is the perception by the landless that traditional school usually doesn't have space for field individuals and its formal structure doesn't allow their entry because the way of teaching disrespects or unaware the reality of the field. It would be necessary that the school would fit in form and 
content to the individuals whom need and participate in it.

So, defending public policies committed to the needs and characteristics of the population living in rural areas, Arroyo (2004) states the people of the field are no more satisfied with old, traditional and compensatory policies which doesn't serve for the cultural dynamics and policy of rural populations. In this way,

The Government and several administrations can no longer treat the education of the field peoples in the same way it was handled for centuries. Precarious forms of rural education management were possible while the field was another. Today the field is different, so the new policies and new management are necessary. The traditional structure management of rural schools was ineffective in the reality of the field. It will be totally ineffective to deal with the developments that are taking place in Brazilian society in general and specificity of human tensions (Arroyo, 2004: p. 58).

However, in the present days it is noted that education of field is still developed in the general way, disregarding the differences between people from the countryside and from the city. There are several problems faced: the distance from the house to the school which in most cases contributes to dropout; poor access to general information; inappropriate curriculum, which is stipulated by government resolutions, aiming at the reality of cities; didactic and methodological deficient structuring; multigrade rooms, with the same program content teaching to children, teenagers and adults in the same space and the same way; school calendar in disagreement with the seasonal production, contributing to lack of students in the school; lack of technical guidance and educational support; lack of school support supplies both for teachers and for students, etc. (Silva, 2004).

According to Arroyo, Caldart, \& Molina (2004: p. 10), these problems contribute to various questions, such as "lack of teacher stimulation, illiteracy, children, adolescents and young people out of school, without schools, age-grade gap, repetition and failure", still remain embedded in education. In this sense, it is important that government policies are implemented in order to strengthen the Brazilian educational system, especially in rural areas once field education plays an important role in the development of these communities, and by their educational action-construction which field's school communities seek greater social, cultural and economic integration, as well as being a diffuser of knowledge and social wisdom (Ramos et al., 2008).

In general, as it will be shown in Section 2.3, education plays an important role in the socioeconomic development of the country, affecting positively the quality of life, productivity and labor income, which imply the need to value this instrument as way to achieve a more uniform society with equity and social justice.

\section{Methodology}

This study has as its object the rural family production, and this analysis verifies 
the impact of education on the environmental performance of rural families from Acre.

The research includes the forest communities of Acre State which live in Extractive Reserves (RESEX) and Agroextractive Settlements Projects (PAE), being part of a family extractive production system.

The collecting of information was accomplished by sampling. The sample is defined by these steps:

1) Stratification of the area according to development level (high, medium or low), taking as reference to the criteria relating to production volumes, ease and quality of access, availability of infrastructure and technical assistance, besides the degree of community organization.

2) Raffle of half the conglomerates of the study areas- "ramais" (stretching unpaved roads), in agricultural areas, and the "seringais" (rubber plantation), in extractive areas-in view of the representative set within each stratum.

See photos of the places studied (QR CODE) Figure 1:

Therefore, from the results it's possible to generalize the data collected for the entire studied region. To survey the information was used as a reference the agricultural calendar of the region, set in conjunction with the communities studied. This calendar refers to the period beginning in May of a year to April of the following year, encompassing the whole of productive economic activities of families.

In this study, it was used the information on the evolution of the families' performance in the period 1996/1997 and 2005/2006, in the Acre's Valley Region, and the period 1999/2001 and 2006/2007 for the Jurua's Valley Region.

The main economic indicators used on current research are briefly described below:

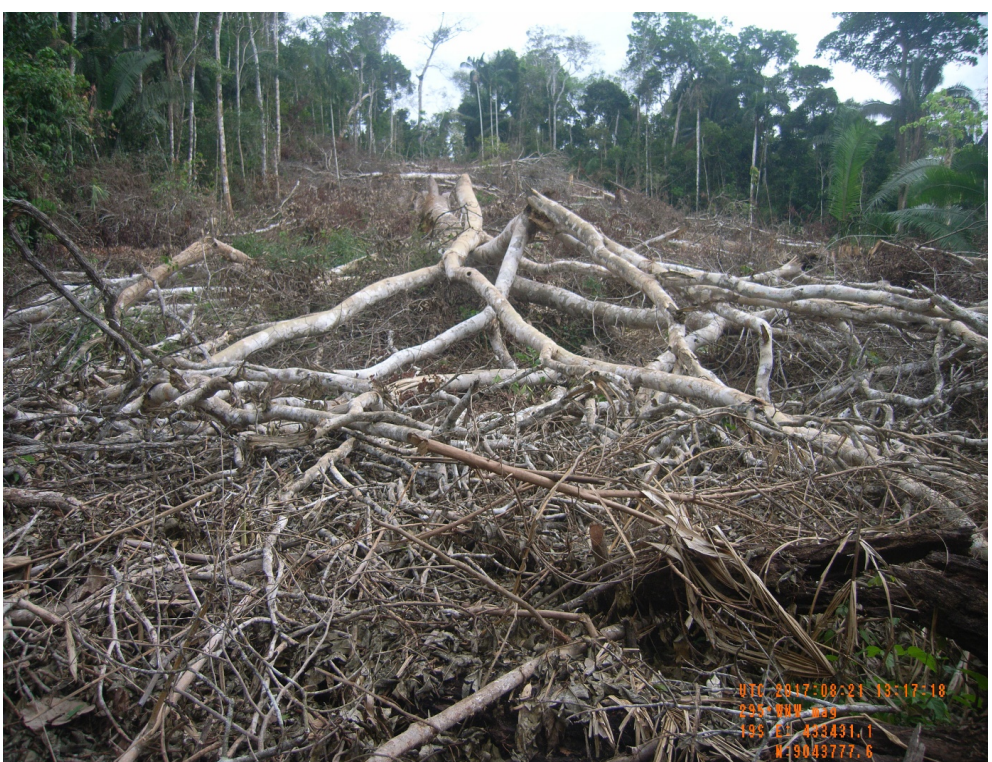

Figure 1. Forest communities of acre State which live in extractive reserves (RESEX). 
1) Gross Income (RB) - indicator for production scale.

2) Family's Gross Margin (MBF) - monetary value available for the family.

3) Self-Consumption (AC) - goods produced and consumed by the family.

4) Economic Efficiency Index (IEE) - indicator for benefit/cost.

5) Value of Consumer goods Purchased on market (VBCC).

6) Exchange Term-is the relationship between the value of the consumer goods purchased and the total production value.

7) Garbage Produced: determined by adding the weight of the packaging of consumer goods purchased on market and the inputs used in production.

8) Educational Level Indicators: It refers to the average level of education of the entire family production unit.

Meaning:

$\mathrm{AT}=$ Completely Illiterate;

EFI = Incomplete Elementary School;

$\mathrm{EFC}=$ Complete Elementary School;

EM_D+ = Educational level from High School.

\section{The Impact of Educational Level on Access and Use of Land of the Family Farming from Acre State}

First, about educational level of the people studied at this research is necessary to indicate that about $20 \%$ of householders are considered illiterate and almost half of these people had studied four years at most-elementary school (1st to 4th grades) - which means a very low level of educational instruction.

According to Figure 2, it is possible to note that land tenure security is directly related to the householders' educational level, once the higher their education level is the higher the land title guarantee of their land will be. It is worth mentioning that the illiterate householders who have the land title (36\%) or has

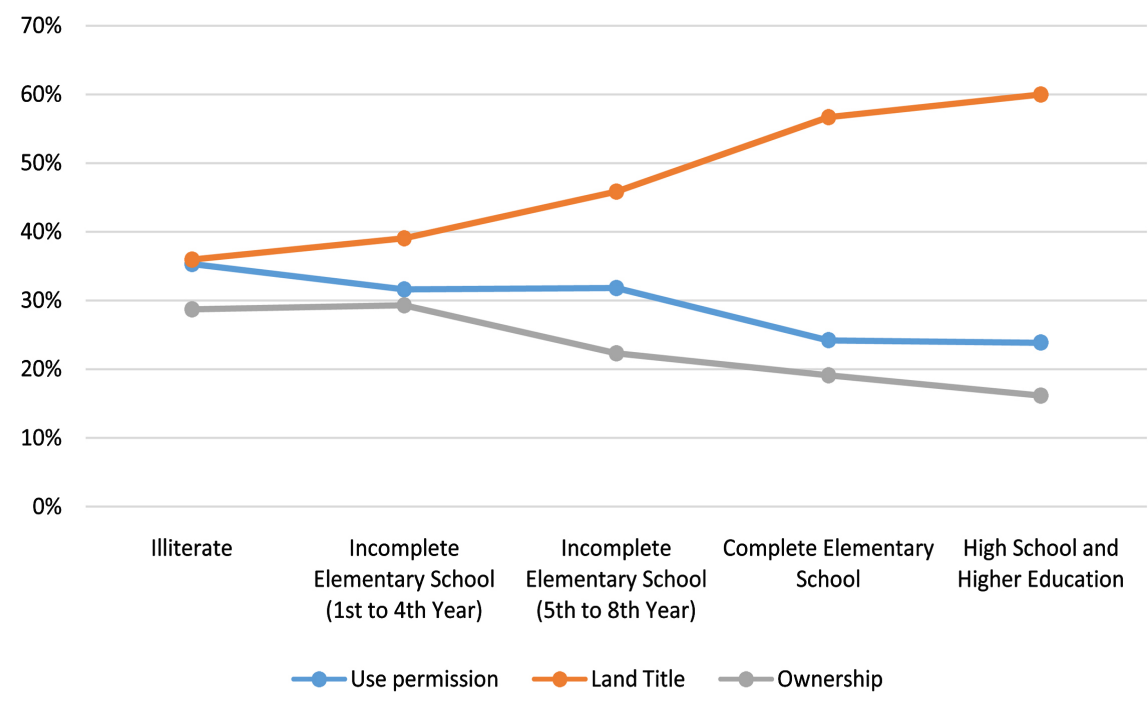

Figure 2. Relationship between the education level and land access of family farming, Acre, Brazil-2006/2007. Source: ASPF (2015). 
use permission (36\%) were probably direct beneficiaries of the land policy program and they haven't sold their land (yet). The squatters (29\%) have acquired their land after the implemented policies program and they are illegal in a regularized area.

As seen in Table 1, there is multidimensional feature of social relations based on land. The illiterate and the majority of producers who have very low education level (only four years of study), because of lack of education, they keep alive the cultural values associated with forest maintenance, with high forest cover in their areas. On the other hand, it is evident that the higher level of education leads the family farmer to deforestation and unsustainable activity by an environmental view, such as the adoption of pastures, whose main destination is the extensively cattle creation.

This situation shows the abandonment of cultural values and it makes the educational issue crucial for proper land use and can put in risk the forest sustainability and families reproduction. Thus, the public policies-particularly those related to land governance-should consider education issue within the sustainable development context, especially in rural areas.

\section{The Education Impact on Environmental Performance of Family Farming in Acre State}

Family farming is of great importance in society, both in food production as in generation of employment and income, besides the environmental aspect. One of the features contributing to the strong family production performance is the fact that labor and management are centralized in the hands of family farmers, and it doesn't occur in non-family farming, so these functions are separated in the production process.

In recent years, the loss of importance of extractive products (such as rubber) in the process of income generation for the acrean families has consistently led the search for productive alternatives "to make money"1, as the need to purchase

Table 1. Relationship between education level and the type of land use of family farming, Acre, Brazil-2006/2007.

\begin{tabular}{ccccc}
\hline \multirow{2}{*}{ Educational Level } & \multicolumn{3}{c}{ Type of Land Use } \\
\cline { 2 - 4 } Illiterate & Forest & $\begin{array}{c}\text { Secondary } \\
\text { Forest }\end{array}$ & Pasture & $\begin{array}{c}\text { Other Open } \\
\text { Areas }\end{array}$ \\
\hline Incomplete Elementary School (1st to 4th) & $96.13 \%$ & $0.26 \%$ & $3.17 \%$ & $0.44 \%$ \\
Incomplete Middle School (5th to 8th) & $78.91 \%$ & $3.49 \%$ & $11.43 \%$ & $6.16 \%$ \\
Complete Middle School & $83.94 \%$ & $2.33 \%$ & $9.78 \%$ & $3.95 \%$ \\
High School & $17.86 \%$ & $0.97 \%$ & $80.03 \%$ & $1.13 \%$ \\
High Education & $70.28 \%$ & $3.42 \%$ & $21.48 \%$ & $4.82 \%$ \\
\hline
\end{tabular}

Source: ASPF (2015).

${ }^{1}$ Popular term used among extractive families. 
goods and services on the market has increased, since it's impossible to produce everything on the family production unit. This leads, for example, to exacerbated manioc production in the Jurua Valley, and cattle farming in the Acre Valley Region, as can be noted from Table 2.

By analyzing the process of income appropriation for rural families in Acre, it is noted from Table 3 that the appropriate income-Family's Gross Margin $(\mathrm{MBF})$, is lower than value of consumer goods purchased on market (VBCC). These values increased sharply in the Acre Valley (89\%) and Jurua Valley (53\%) demonstrating a greater connection with the vicious circle of capitalist and urban consumerism, which is increasingly spreading inside the forests. Thus, if the income becomes lower than value of goods purchased from the market, the family heads go through debt and constant default, both in trade as in the credit market.

Table 2. Gross income generation in forest communities in acre valley region and JURUá Valley, Acre, Brazil-2005/2006 and 2006/2007.

\begin{tabular}{ccccc}
\hline \multirow{2}{*}{ Activity/Product } & \multicolumn{4}{c}{ Gross Income Generation(\%) } \\
\cline { 2 - 5 } & \multicolumn{2}{c}{ Acre Valley Region } & \multicolumn{2}{c}{ Juruá Valley } \\
\cline { 2 - 5 } & $2005 / 2006$ & Evolution $(\%)^{*}$ & $2006 / 2007$ & Evolution (\%) ${ }^{* *}$ \\
\hline Extrativism & 47.35 & -2.78 & 7.60 & -69.75 \\
Nut & 27.05 & 8.93 & - & - \\
Rubber & 7.02 & -70.57 & 4.90 & -77.78 \\
Timber & 5.96 & - & 2.70 & - \\
Others & 7.32 & - & - & - \\
Breeding & 31.81 & 17.19 & 21.11 & $-\mathbf{4 0 . 1 8}$ \\
Cattle & 21.31 & 69.13 & 7.81 & -26.27 \\
Others & 10.50 & - & 13.30 & - \\
Agriculture & 20.84 & -13.72 & 71.29 & $\mathbf{8 0 . 0 8}$ \\
Manioc & 8.42 & 21.50 & 58.73 & 176.62 \\
Others & 12.42 & - & 12.56 & -
\end{tabular}

Note: ${ }^{\star}$ Evolution considering the period 1996/1997; ${ }^{* *}$ Evolution considering the period $1999 / 2001$. Source: ASPF (2015)

Table 3. Economic indicators selected for the extractive forest communities, Acre and Jurua Valleys, Acre, Brazil-1996/1997, 2005/2006 and 1999/2000, 2006/2007.

\begin{tabular}{cccccc}
\hline \multirow{2}{*}{$\begin{array}{c}\text { Economic } \\
\text { Indicators }\end{array}$} & \multirow{2}{*}{ Und. } & \multicolumn{2}{c}{ Acre Valley } & \multicolumn{2}{c}{ Jurua Valley } \\
\cline { 3 - 6 } & & $2005 / 2006$ & Evolution (\%) & $2006 / 2007$ & Evolution (\%) \\
\hline RB & R\$month & 666.12 & $39.41 \%$ & 296.36 & $-19.02 \%$ \\
MBF & R\$/month & 530.51 & $44.21 \%$ & 240.62 & $-22.25 \%$ \\
VBCC & R\$/month & 1278.32 & 89.05 & 1242.71 & $53.47 \%$ \\
AC & R\$/month & 226.32 & $-24.70 \%$ & 156.83 & $-65.49 \%$
\end{tabular}

Ps.: 1. Average results by rural family production extractive unit; 2. Values updated by INPC until March 2014. Source: ASPF (2015). 
From these data appear the questionings about the complete dependence of the market-pushed by capitalist forces-since the self-consumption (AC) has become weaker, especially by low income that hinder the production for subsistence, in addition to the attractiveness of products available in the market at more affordable prices than those ones produced in family units.

In Table 4, it appears that the main goods that are purchased in the market by rural families of Acre are foodstuffs, clothing and hygiene products and cleaning. The high level of food purchased on the market demonstrates, in a way, the unfeasibility or at least a tendency to inefficiency of the production units in the process of social reproduction, since it can't produce part of staple foods such as rice, beans, etc.

In this sense, the forest population begins to acquire various industrial goods, even those incompatible to the reality in the field, such as various electronic devices (e.g., mobile phones) that doesn't even work in rural areas, but reflect a status. This causes the increasing generation of garbage in rural areas, with a further environmental degradation caused mainly by indiscriminate disposal of waste inside the forests, contributing to the emission of greenhouse gases, pollution and contamination of air, water and soil also causing social impacts, such as the disappearance of traditional populations.

Table 5 shows the amount of garbage $(\mathrm{kg})$ generated per person and per family

Table 4. Consumer goods categories purchased in the market: Acre and jurua valley, acre, Brazil-2005/2006 and 2006/2007.

\begin{tabular}{ccccc}
\hline Discrimination & $\begin{array}{c}\text { Acre Valley } \\
(2005 / 2006)\end{array}$ & $\begin{array}{c}\text { Evolution } \\
(\%)\end{array}$ & $\begin{array}{c}\text { Juruá Valley } \\
(2006 / 2007)\end{array}$ & $\begin{array}{c}\text { Evolution }^{* *} \\
(\%)\end{array}$ \\
\hline Food & $52.96 \%$ & $-5.93 \%$ & $52.93 \%$ & $-3.52 \%$ \\
Clothing & $19.58 \%$ & $-4.88 \%$ & $19.60 \%$ & $-5.14 \%$ \\
Others products & $13.99 \%$ & $13.94 \%$ & $13.98 \%$ & $38.95 \%$ \\
Hygiene/cleaning & $13.48 \%$ & $15.86 \%$ & $13.49 \%$ & $-19.08 \%$ \\
\hline
\end{tabular}

Note: ${ }^{\star}$ Evolution considering the period $1996 / 1997 .{ }^{* *}$ Evolution considering the period $1999 / 2000$. Source: ASPF (2015).

Table 5. Waste (garbage) generated by forest communities of acre, Brazil-2005/2006 e 2006/2007.

\begin{tabular}{ccccccccc}
\hline & \multicolumn{3}{c}{ Acre Valley (2005/2006) } & \multicolumn{3}{c}{ Jurua Valley (2006/2007) } \\
\cline { 2 - 9 } Waste & $\begin{array}{c}\text { Kg/hab./ Kg/UPF/ } \\
\text { day }\end{array}$ & Kgy $/$ total/ & year* & $\begin{array}{c}\text { Evolution } \\
\text { da }\end{array}$ & $\begin{array}{c}\text { Kg/hab./ } \\
\text { day }\end{array}$ & $\begin{array}{c}\text { Kg/UPF/ } \\
\text { day }\end{array}$ & $\begin{array}{c}\text { Kg/total/ } \\
\text { year }\end{array}$ & $\begin{array}{c}\text { Evolution } \\
(\%)\end{array}$ \\
\hline Plastic & 0.04 & 0.18 & $281,861.32$ & 1438 & 0.02 & 0.12 & $156,455.92$ & 928 \\
Metal & 0.01 & 0.04 & $63,462.66$ & 150 & 0.01 & 0.03 & $42,193.85$ & 6.0 \\
Glass & 0.00 & 0.01 & $23,164.40$ & 308 & 0.00 & 0.02 & $22,932.77$ & 19 \\
Battery & 0.00 & 0.01 & $10,455.78$ & -12 & 0.00 & 0.01 & $14,765.73$ & 69 \\
Paper & 0.00 & 0 & 6614.30 & 244 & 0.00 & 0.00 & 1827.95 & 46 \\
Total & $\mathbf{0 . 0 5}$ & $\mathbf{0 . 2 4}$ & $\mathbf{3 8 5 , 5 5 8 . 4 6}$ & $\mathbf{5 0 9}$ & $\mathbf{0 . 0 3}$ & $\mathbf{0 . 1 9}$ & $\mathbf{2 3 8 , 1 7 6 . 2 3}$ & $\mathbf{1 8 3}$ \\
\hline
\end{tabular}

${ }^{\star}$ Related to 4.326 UPF's or house (5 people average/UPF); ${ }^{*}$ Related to 3.492 UPF's (6 people average/UPF). ${ }^{2}$ Refers to the period $1996 / 1997 ;{ }^{3}$ Refers to the period 1999/2001. Source: ASPF (2015). 
production unit (UPF) in rural areas of Acre. In recent years, the consumption of products whose packages are difficult to decompose in nature is very high. Among the main waste generated is plastic, which had a generation of $281,861.32 \mathrm{~kg} /$ total/year in the Acre Valley region, and 156,455.92 kg/total/year in the Jurua Valley. According to literature, plastic usually takes around 500 years to decompose; other waste such as metal, almost neither even come to decompose; and glass doesn't have a determined time for decomposition.

Quantitatively, the table 5 shows in the interstices of a decade, waste produced amount increased more than 500\% in Acre Valley-producing 385,558.46 tons per year-and $183 \%$ in Jurua Valley-resulting in 240 tons/year of garbage. The total waste produced in Acre forests amounted to more than 620 tons/year in the analyzed period.

The problem is that $84 \%$ (Figure 3 ) of the garbage generated by forest communities in Acre State is buried, burned, disposed open air (soil and water), causing serious damage to environment and to human health. The question that must be discussed is about the ecosystem support capacity over the years, as well the types of contamination caused or future damage due to the improper waste disposal.

To get a better idea of the problem seriousness, for example, the data show that non-rechargeable batteries (39\%) and rechargeable batteries (34\%) are largely buried or thrown open air (22\%) and even burned or deposited in body of water available in the communities. It is known that these products have in their composition toxic substances which, when disposed improperly, can result in many complications, as soil and water contamination, even diseases that can extremely affect the human health. The market contribution in this question is

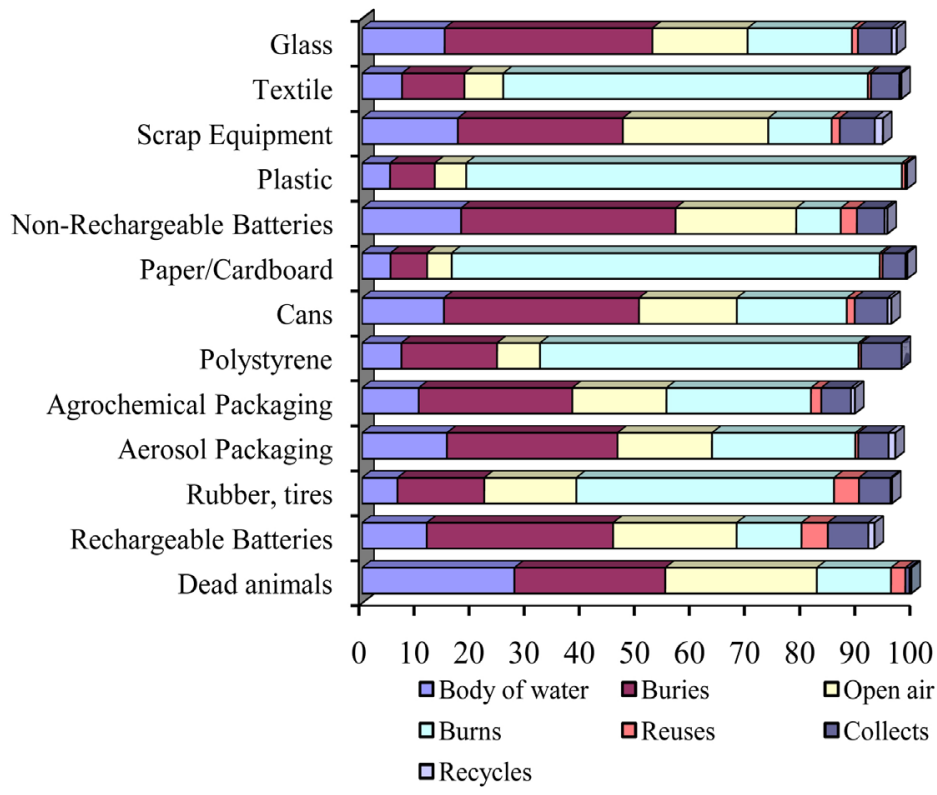

Figure 3. Garbage disposal by waste type in rural areas in Acre (\%). Source: ASPF (2015). 
fundamental for providing collection points for batteries and other containers and packaging.

In addition to these materials, it can be seen that $79 \%$ of plastic, $78 \%$ of paper/paperboard, $58 \%$ of polystyrene and $47 \%$ of tire/rubber are burned in Acre's forest communities. It demonstrates a troubling situation regarding to environmental issues, as these industrialized materials don't decompose easily in nature.

When analyzing the waste type produced by level of education in Acre's rural areas, it is noted from Figure 4 when individuals reach higher levels of education, they begin to demand other goods acquired by market, especially the industrialized ones. It is observed, for example, an increase of $41 \%$ in using rechargeable batteries replacing non-rechargeable batteries from those who attended at least High School. This is due that prior to the increase of schooling, radio was the only device used in communities. From raising the educational level it starts the demand for other electronics that work through batteries, like mobile phones. This reflects the education implemented in rural areas is based in city style, without a direction to the reality in the field.

When analyzing the garbage destination by level of education, in Figure 5 it

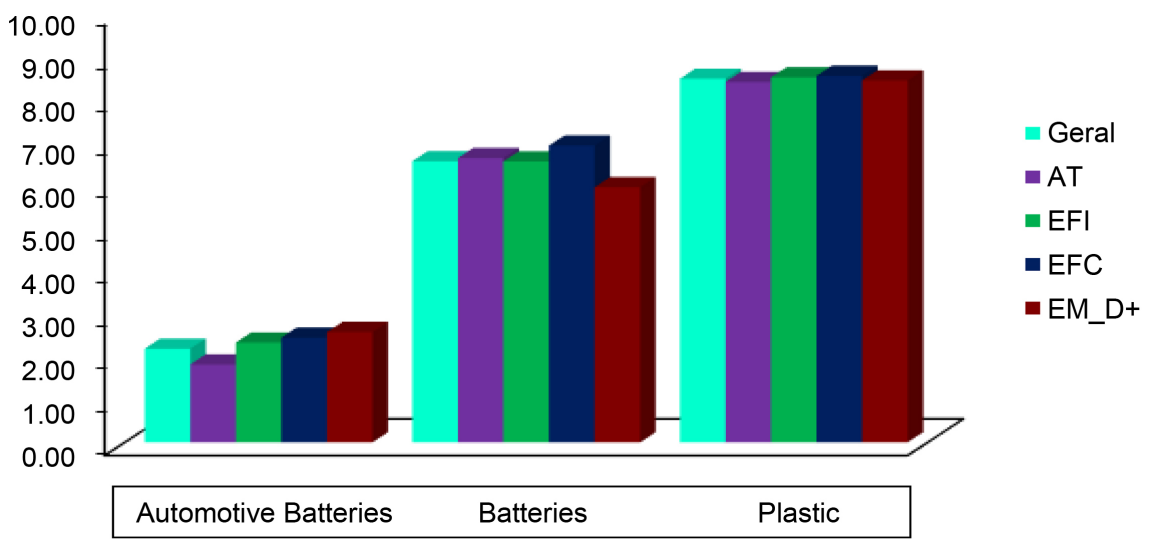

Figure 4. Waste type by educational level in rural areas, acre, Brazil-2005/2007 (\%). PS.: AT-Completely Illiterate; EFI_Elementary School Incomplete; EFC—Elementary School Complete; EM_D+-Educational level from High School. Source: ASPF (2015).

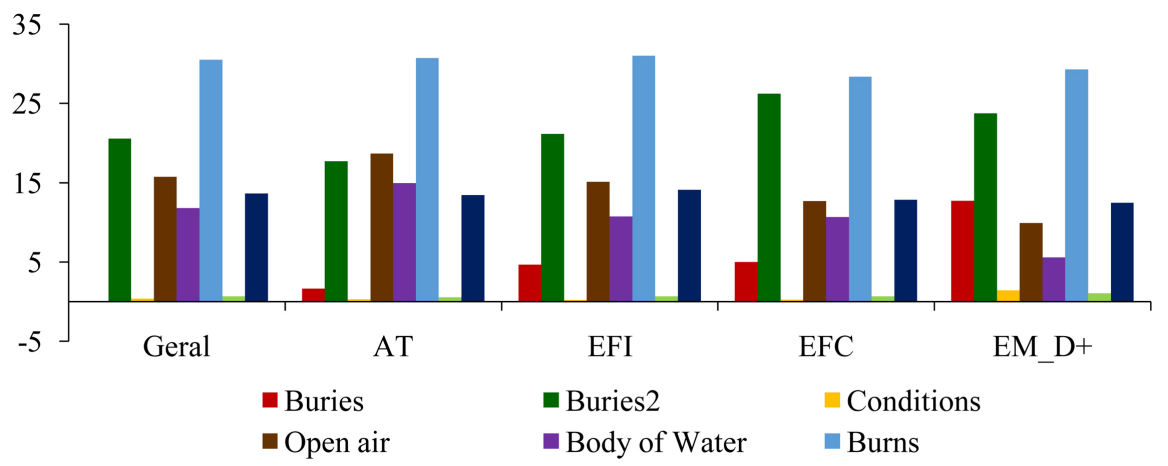

Figure 5. Garbage disposal by education level in Acre forests (\%). PS.: AT-Completely Illiterate; EFI-Elementary School Incomplete; EFC-Elementary School Complete; EM_D+_Educational level from High School. Source: ASPF (2015). 
can be seen that from the moment there was an increase in the educational level of the individuals they started to give a more suited destination to their waste. For example, those who achieve education from high school, there was a decrease in $6 \%$ of the waste that was previously burned by households who were complete illiterates. The same applies to the disposal in the open air and in the water, which reduced $47 \%$ and $62 \%$, respectively, from the complete illiterate to the high school.

The decrease in the burning process occurred from raising the education level causing a significant increase in the waste packaging process in closed locations (545\%), collection (171\%) and recycling (47\%) that began to be a behavior of some family members within the production units which have studied Incomplete Elementary School, rising greatly to the ones which attended High School.

There was also a $34 \%$ increase in the burying process of waste generated based on the high level of education. This indicates that producers believe by burying the waste they are giving a correct destination, however, without knowing the consequences to the families.

Nevertheless, even rising the garbage produced amount by family units in Acre as there has been increased in income; it's possible to note that the educational level plays a key role in the environmental awareness formation. Through research, it was found that from incomplete Elementary School occurred behavioral changes regarding the destination of the waste. There was, for example, increased process of selective collection, recycling, burial, and waste packaging indoors. Also, a decrease in the open air and in water bodies dump as well as in the waste burning.

\section{Conclusion}

Recently topics on land governance and land pro-poor policies returned to the debates, notably related to the production of food and agrofuels associated with big enterprises to the detriment of family farming.

A key issue in discussion about governance is to consider the social relations between people and institutions based on land and its multidimensional character, especially in the non-economic dimensions.

The study showed that the educational variable is essential to forward the discussions on land access, especially in titled areas, and appropriate use of land, as the results indicated that the lack of adequate educational instruction can lead to forest areas deforestation and to related problems such as loss of biodiversity.

Moreover, the production difficulties of families led to a greater reliance on the market to buy goods, especially industrial ones. This increased the generation of solid waste in rural areas, characteristically urban, such as plastics and metals. Those individuals with higher incomes buy in the market more potentially polluting products, as the use of non-rechargeable and rechargeable batteries. However, the higher level of education of some producers also indicates greater environmental awareness, even working inadequate solutions in packag- 
ing and disposal of waste.

\section{References}

Arroyo, M. G. (2004). Por um tratamentopúblico da educação do campo. In M. C. Molina, \& S. M. S. Azevedo De Jesus (Org.), Contribuiçôes para a construção de um projeto de educação do campo. ColeçãoPorumaEducação do Campo, nº 05, Brasília, DF: Articulação Nacionalporuma Educação do Campo.

Arroyo, M. G., Caldart, R. S., \& Molina, M. C. (Org.) (2004). Porumaeducação do campo. Petrópolis, RJ: Vozes.

Barbieri, J. C., \& Silva, D. (2011). Desenvolvimento Sustentável e Educação Ambiental: Uma trajetóriacomum com muitosdesafios. Revista de Administração Mackenzie, 12, 51-82. https://doi.org/10.1590/S1678-69712011000300004

Borras, S., \& Franco, J. (2010). Contemporary Discourses and Contestations around Pro-Poor Land Policies and Land Governance. Journal of Agrarian Change, 10, 1-32. https://doi.org/10.1111/j.1471-0366.2009.00243.x

Caldart, R. S. (2004). Aescola do campo emmovimento. In R. S. Caldart, \& M. C. Molina (Org.), Porumaeducação do campo. Petrópolis, RJ: Vozes.

da Veiga, J. E. (2014). Entender a Sustentabilidade. São Paulo: Valor Econômico. http://www.valor.com.br/

de Oliveira, L. M. M., \& Hage, S. A. M. (2011). A Socioterritorialidade da Amazônia e as políticas de educação do campo. RevistaEducação, 12, 141-158.

FAO (2009) Towards Voluntary Guidelines on Responsible Governance of Tenure of Land and Other Natural Resources (p. 10). Rome, FAO, Land Tenure Working Paper.

FAO (2014). The State of Food and Agriculture: Inovation in Family Farming. Rome: FAO. https://www.fao.org.br/download/SOFI_i2.pdf

Gadotti, M. (2010). Reorienting Education Practices towards Sustainability. Journal of Education for Sustainable Development, 4, 203-211. https://doi.org/10.1177/097340821000400207

Gottlieb, D., Vigoda-Gadot, E., Haim, A., \& Kissinger, M. (2011). The Ecological Footprint as an Educational Tool for Sustainability: A Case Study Analysis in an Israeli Public High School. International Journal of Educational Development, 32, 193-200. https://doi.org/10.1016/j.ijedudev.2011.03.007

Guanziroli, C. et al. (2001). Agricultura Familiar e Reforma Agrária no Século XXI. Rio de Janeiro: Garland.

Henriques, R. et al. (2007). EducaçãoAmbiental: Aprendizes de sustentabilidade. Brasília: Cadernos SECAD.

Jacobi, P. (2004). Educação e meioambiente: Transformando as práticas (pp. 28-35). Brasília: Revista Brasileira de Educação Ambiental.

Komiyama, H., \& Takeuchi, K. (2006). Sustainability Science: Building a New Discipline. Sustainability Science, 1, 1-6. https://doi.org/10.1007/s11625-006-0007-4

Maciel, R. C. G. (2007). CertificaçãoAmbiental: Umaestratégia para a conservação da florestaamazônica (175 p). Tese de Doutorado, EconomiaAplicada, IE/UNICAMP.

Payne, G., Durand-Lasserve, A., \& Rakodi, C. (2009). The Limits of Land Titling and Home Ownership. Environment and Urbanisation, 21, 443-462. https://doi.org/10.1177/0956247809344364

Prazeres, M. S. C., \& Souza do Carmo, E. (2012). Retratos e desafios da educação do/no campo no Brasil e naAmazônia. RevistaOlhar de Professor, Paraná, 15, 383-395. 
https://doi.org/10.5212/OlharProfr.v.15i2.0012

Quan, J. (2015). Family Farming and Land Governance: Towards a People-Centred Approach: Synthesis of Findings of a Research Project Supported by the International Land Coalition. Paper Presented at the Annual World Bank Conference on Land and Poverty.

Ramos, V. G. et al. (2008). Educação rural e desenvolvimento sustentável: Umaexperiênciapartir do ensino da geografia escola estadual de ensino fundamental nossa senhora aparecida, Júlio de Castilhos, RS. In $4^{\circ}$ Encontro Nacional de Grupos de Pesquisa (pp. 574-592). São Paulo: Engrup.

Reydon, B. P. (2014). Governança de terras e a questãoagrária no brasil. In A. C. Buainain, E. Alves, J. M. Silveira, \& Z. Navarro (Eds.), O mundo rural no Brasil do século 21: A formação de um novo padrãoagrário e agrícola (pp. 725-759). Brasília: Embrapa.

Romeiro, A. R. (2012). Desenvolvimento Sustentável: Uma perspectiva econômico-ecológica (Vol. 26, No. 74). São Paulo: EstudosAvançados.

SÁ, P. A. P. (2008). Educação para o DesenvolvimentoSustentável no $1^{\circ}$ CEB: Contributos da Formação de Professores (495 p). Dissertação (DoutoramentoemDidáctica), Universidade de Aveiro.

Silva, M. S. (2004). Educação do campo e desenvolvimento: Uma Relação Construída Ao Longo da história.

http://www.contag.org.br/imagens/f299Educacao_do_Campo_e_Desenvolvimento_Sus tentavel.pdf

UNESCO (2005). Década da educação das NaçôesUnidas para um desenvolvimento sustentável, 2005-2014: Documento final do esquema internacional de implementação (120 p). Brasília: Unesco. 